\title{
The CIA's Secret Funding and the Constitution
}

If you knew how much we spend and how much money we waste in this area, it would knock you off your chair. It's criminal!

\author{
Senator Allen Ellender \\ commenting on United \\ States intelligence \\ activities in $1971^{1}$
}

Once again the Central Intelligence Agency (CIA) is in the news. The controversy now focuses on an alleged massive intelligence operation by the CIA against groups in the United States, ${ }^{2}$ rather than on the necessity or wisdom of CIA covert intervention in Chile. ${ }^{3}$ However, it has largely ignored a prior issue, the massive secrecy that envelops the CIA. Even the simple total of CIA expenditures, estimated now at $\$ 750$ million, ${ }^{4}$ is kept from the public. In addition, Congress as a whole makes no appropriation to the CIA; the agency's funds are covertly transferred from the appropriations made to other governmental units. 5 The vast majority of Congress-and the publicknow nothing of the amounts involved. This funding secrecy may be unconstitutional.

Article I, $\S 9$, Clause 7 of the Constitution provides:

No Money shall be drawn from the Treasury but in Consequence of Appropriations made by Law; and a regular Statement and Account of the Receipts and Expenditures of all public Money shall be published from time to time.

1. Wash. Post, Dec. 9, 1973, at A 9, col. 8. Ellender was then Chairman of the Intelligence Subcommittee of the Senate Appropriations Committee.

2. See N.Y. Times, Dec. 22, 1974, \& 1, at 1, col. 8; Dec. 25, 1974, at 1, col. 8; Dec. 29, 1974, $\$ 1$, at 1, col. 1; Dec. 30, 1974, at I, col. 3; Wash. Post, Dec. 25, 1974, at A 1, col. 6. 8.

3. See N.Y. Times, Sept. 8, 1974, at 1, col. 7; Sept. 21, 1974, at 12, col. 3; Sept. 22, 1974, $\$ 4$, at 21, col. 2; Oct. 21, 1974, at 2, col. 3; Oct. 23, 1974, at 2, col. 2; Wall St. J., Dec. 9, 1974, at 1 , col. 4 .

4. 119 Conc. Rec. S6868 (daily ed. Apr. 10, 1973) (remarks of Sen. Proxmirc). Marchetti and Marks would place the actual expenditures substantially higher. V. MARCHETr \& J. MARKS, THE CIA AND THE CULT OF INTELLIGENCE 59-73 (1974) [hereinafter cited as MARCHETTI \& MARKs]. Marchetri \& Marks, published with a number of deletions suggested by the CIA, has been the subject of litigation. See, e.g., United States v. Marchetti, 466 F.2d 1309 (5th Cir.), cert. denied, 409 U.S. 1063 (1972). The final form of the book will be determined by rulings on appeals by both parties.

5. 50 U.S.C. $403 \mathrm{f}$ (a) (1970) authorizes the CIA to "transfer to and receive from other Government Agencies such sums as may be approved by the Office of Management and Budget for the performance of any of the functions or activities authorized under Sections 403 and 405 of this title..." See generally N.X. Times, Dec. 29, 1974, § 4, at I, col. 5. 
On its face the Clause permits no exceptions to the requirement of an appropriation and an accounting. But the Clause is not self-defining; the first part leaves open the question of what are "appropriations made by law." The second part defines neither "regular statement and account" nor "from time to time." Cases involving the Clause $^{6}$ have been rare and have provided no definitive test against which the CIA practice can be measured. Moreover, the Supreme Court is unlikely to pass on the constitutionality of the practice in the near future. Just last term, in United States $v$. Richardson, ${ }^{7}$ the Court held by a five-four majority that a plaintiff lacked standing as a taxpayer under the Clause to compel publication of the CIA's expenditures. But the constitutional issue is by no means foreclosed. The Court failed to reach the merits, and there may yet be plaintiffs-members of Congress, for example ${ }^{8}$-who could surmount the standing barrier.

This Note defines the meaning of the Clause by examining its language, history, and purposes, and it analyzes possible justifications for the present funding and disclosure practices. It concludes that the failure to make a specific appropriation to the agency and the failure to provide information about expenditures to the public are violations of the Constitution. Finally, it suggests the outlines of a test for budgetary disclosure in security-sensitive government operations.

\section{The History of the Clause}

Clause 7 was not the subject of extensive debate at the Constitutional Convention. The first part of the Clause, providing for congressional power over appropriations, was introduced early in the convention ${ }^{9}$ and remained basically unchanged. ${ }^{10}$

This congressional power took on a new importance in light of

6. See cases cited in notes 7, 35-39 infra.

7. 94 S. Ct. 2940 (1974).

8. See generally Note, Standing to Sue for Members of Congress, 83 YALE L.J. 1665 (1974). Other possible plaintiffs range from CIA pensioners, see MARchetTI \& MARKs, supra note 4 , at $64-65$, to voters alleging that their franchise has been impaired because of the lack of constitutionally mandated disclosure of information on receipts and expenditures of public money.

Even if no plaintiff were found to have standing, the issue of what constitutes compliance with the constitutional requirement is still important to Congress and to the agencies responsible for transferring funds to the CIA and for preparing the accounts required by the Constitution.

9. 1 M. Farrand, Records of the Federal Convention of 1787, at 524, 545 (1911) [hercinafter cited as RECoRDs].

10. 2 id. at $14,280,509$. 
the grant to Congress of the power to impose customs and levy taxes, a grant which marked a significant change from the system under the Articles of Confederation. ${ }^{11}$

The idea of an accounting of government spending; required under the second part of the Clause, was familiar; a provision for an accounting had existed under the Articles. ${ }^{12}$ Yet no similar provision was proposed until the closing days of the Convention ${ }^{13}$ when Mason introduced a clause requiring that an account of public expenditures be published annually. ${ }^{14}$ Madison proposed to replace "annually" with language that would leave the timing of the publication to the legislature. ${ }^{15}$ Supporters of Madison's amendment argued that if the interval were fixed and proved to be too short, the statements would cease as they had done under the Articles, ${ }^{16}$ be incomplete, ${ }^{17}$ or be too general to be satisfactory. ${ }^{18}$ The amendment was adopted and the Glause rephrased to its present form with reports to be published "from time to time."19

At the state ratifying conventions the issue arose once more. It

11. Under the Articles of Confederation, only the states, not the central government, could levy taxes. See H. Hocketr, A Constimutional History of the United States 149 (1939).

12. Article IX of the Articles of Confederation provided that the

United States in Congress asscmbled shall have the authority to ascertain the necessary sums of money to be raised for the service of the United States and to appropriate and apply the same for defraying the public expenses-to borrow money or emit bills on the Credit of the United States transmitting every half-year to the respective states an account of the sums so borrowed or emitted.

The provision for a report may not have been particularly important under the Articles, as the central government did not have the power to levy taxes. Whatever its importance, as a matter of practice reporting had ceased under the Articles. See note 15 infra.

13. It was considered, after the Committee of Style had reported its draft of the Constitution, along with a number of measures which some members of the Convention felt were "trivial" and were "delaying the completion of the work." M. FARRAND, ThE Framing OF THE Constitution of THE UNITED STATEs 188-89 (1913). Among these items were the prohibition of capitation or any other direct tax and the prohibition of state laws impairing the obligation of contracts. Id. Farrand suggests that some of these were accepted by the majority as long as no important principles were involved in order that the final action of the Convention would be unanimous. Id. This, however, should not be taken to mean that the principles represented by the additions, were unimportant. See, e.g., Pollock v. Farmers' Loan \& Trust Co., 157 U.S. 429 (1895); U.S. CoNST. amend. XVI.

14. 2 Reconds, supra note 9 , at 618 .

15. Mr. Madison proposed to strike out "annually" from the motion s insert "from time to time" which would enjoin the duty of the frequent publications and leave enough to the discretion of the Legislature. Require too much and the difficulty will beget a habit of doing nothing. The articles of Confederation require half-yearly publications on this subject-A punctual compliance being often impossible, the practice has ceased altogether.

$I d$. (reproducing the original record).

16. Id.

17. Id. at 619 (statement of Fitzsimmons).

18. "Mr. King remarked, that the term expenditures went to every minute shilling. This would be impracticable. Congs. might indeed make a monthly publication, but it would be insuch general Statements as would afford no satisfactory information." Id. at 618.

19. Id. at 619 . 
was argued that the absence of a fixed interval could result in no information being published and might in fact allow misapplication of funds to be concealed forever. ${ }^{20}$ Proponents of the Clause again responded that leaving the interval to be fixed by Congress would result in fuller information being published, since no agency would be forced to publish an incomplete report to meet an inflexible and unrealistic deadline. ${ }^{21}$ They ridiculed the possibility that giving Congress discretion as to the frequency of publication would mean that information would be concealed forever; Congress would publish the reports at regular, frequent intervals. ${ }^{22}$

The debates yield no detailed or comprehensive statement of the purposes of the Clause. No one, however, disagreed with Mason's assertion that the public had a "right to know" how the public money was being spent. ${ }^{23}$ The main problem considered in the debates was how best to make such information available in a fashion which would allow for its "thorough comprehension." 24

\section{The Purposes of the Clause}

Congress's power and responsibility under the Clause could be given a broad or a narrow reading, as could the people's right to information. It is important, therefore, that the Clause be viewed in the light of its place in the larger constitutional structure. ${ }^{25}$ Under the form of government established, the powers of government

20. See, e.g., D. Robertson, Debates and other Proceedings of the Convention of VIRGINI, 1788, at 326 (1805); p. 622 infra.

In New York, Smith echoed Mason's fear that the statements might be withheld until the information in them was useless. "From time to time" he noted might mean "from century to century." The Chancellor of New York replied, asking "[I]f the public werc more anxious about any thing under heaven than the expenditure of their money. Will not the representatives... consider it as essential to their popularity, to gratify their constituents with full and frequent statements of the public accounts? There can be no doubt of it." 2 J. Elliot, Debates in the Sevfrai. State Conventions on the Adormon of THE FEDERAl Constitution 347 (1836). The New York convention was not as sanguine as the Chancellor and voted a proposed amendment to the Constitution which read in part, "Provided that the words from time to time shall be so construed, as that the receipts and expenditures of public money shall be published at least once in every year...." $1 d$. at 407.

21. See p. 622 infra.

22. Lee labelled Mason's argument trivial. "From time to time" was "sufficiently explicit and satisfactory," and meant, "in the common acceptance of language, short, convenient periods." D. RoBERTson, supra note 20 , at 326 .

23. Id. (remarks of George Mason). See generally 3 Records, supra note 9, at 149-50 ("when the Public Money is lodged in its Treasury...t the People who give their Money ought to know in what manner it is expended") (remarks of James McHenry before the Maryland House of Delegates). Nor was there any suggestion in the debates that Congress could or would deprive itself of the information.

24. See p. 622 infra.

25. For a presentation of this type of approach, see C. BLACK, Srructure and RecaTIONSHIP IN CONSTITUTIONAL LAW (1969). 
rest upon the consent of the governed. ${ }^{26}$ Such a system is based on full public participation which in turn depends on the public's access to information. ${ }^{27}$ As Madison wrote:

A popular Government, without popular information, or the means of acquiring it, is but a Prologue to a Farce or a Tragedy; or perhaps both. Knowledge will forever govern ignorance. And a people who mean to be their own Governors, must arm themselves with the power which knowledge gives. ${ }^{28}$

The importance of such participation and information has been recognized in numerous ways. The Supreme Court has evolved a definition of the First Amendment which is based on the necessity of "uninhibited, robust and wide-open"29 debate on public issues. Congress through several measures ${ }^{30}$ has established a policy of maximum possible disclosure based on the premise that "[a] democratic society requires an informed, intelligent electorate, and the intelligence of the electorate varies as the quantity and quality of its information varies." ${ }^{31}$ Even the latest revision of the system of executive classi-

\section{See Declaration of Independence:}

[T]o secure these Rights, Governments are instituted among Men, deriving their just Powers from the Consent of the Governed....

Cf. H. ARENDT, CRISES OF THE REPublic 85 (1972) (analysis of the concept of the consent of the governed in America, concluding that it necessarily entails "consent, not in the very old sense of mere acquiescence, with its distinction between rule over willing subjects and rule over unwilling ones, but in the sense of active support and continuing participation in all matters of public interest").

27. The withholding of information eventually leads to a diminished participation in government, J. Wigcins, FreEdom OR SECRECY? (1964), because the citizen feels that he or she is the victim of propaganda and has nothing to add to the debate but personal suspicions. H. Lasswell, National Security and Individual Freedoni 35-36 (1950). As President Nixon wrote:

When information which properly belongs to the pcople is systematically withheld by those in power, the people soon become ignorant of their own affairs, distrustful of those who manage them, and eventually incapable of determining their own destiny. Quoted in HARv. L. Sch. Bull., June 1973, at 8.

28. Letter to W.T. Barry, Aug. 4, 1822, in 9 The WWrings of JAmes Misdison 103 (G. Hunt ed. 1910).

29. New York Times Co. v. Sullivan, 376 U.S. 254, 270 (1964); Abrams v. United States, 250 U.S. 616, 630 (1919) (Holmes, J., dissenting). Obviously without access to information "the uninhibited, robust, and wide-open debate" envisioned in Sullivan becomes exchange without substance. See Rosenbloom v. Metromedia, Inc., 403 U.S. 29, 11 (197I); Unitcd States v. Caldwell, 408 U.S. 665, 715 (1972) (Douglas, J., dissenting) ("[e]ffective selfgovernment cannot succeed unless the people are immersed in a steady, robust, unimpeded, and uncensored flow of opinion and reporting which are continuously subjected to critique, rebuttal, and recxamination").

30. See, e.g., Freedom of Information Act, 5 U.S.C. $\$ 552$ (1970), as amended, 197t Amendinents to the Freedom of Information Act, Pub. L. No. 93-502 (Nov. 21, 197.); National Environmental Policy Act (NEPA), 42 U.S.C. $\$ 4321-47$ (1970). Section 102(c), id. $\$$ 4332 (c), of the NEPA has been interpreted as providing a means of bringing the critical cvaluation of the public to bear on administrative agency decisionmaking. Environmental Defense Fund v. Froehlke, 473 F.2d 346, 351 (8th Cir. 1972) (Army Corps of Engincers' environmental impact statement held inadequate to meet requirements of $\$ 102(\mathrm{c})$ ).

31. H.R. REP. No. 1497, 89th Cong., 2d Sess. 12 (1966). 
fication, ${ }^{32}$ which is designed to restrict access to information, was based on the asserted ground that government information should be readily available to the public. ${ }^{33}$

Both parts of the Clause are important; the purposes of each merit separate treatment. Justice Story, writing in the early 19th century, succinctly described the purposes of the first part:

It is to secure regularity, punctuaiity, and fidelity, in the disbursements of the public money. As all the taxes raised from the people, as well as the revenues arising from other sources, are to be applied to the discharge of the expenses, and debts, and other engagements of the government, it is highly proper, that Congress should possess the power to decide how and when any money should be applied for these purposes. If it were otherwise, the executive would possess an unbounded power over the public puise of the nation, and might apply all its moneyed resources at his pleasure. The power to control and direct the appropriations constitutes a most useful and salutary check upon profusion and extravagance, as well as upon corrupt influence and public peculation .... It is wise to interpose in a republic, every restraint, by which the public treasure, the common fund of all, should be applied with unshrinking honesty to such objects as legitimately belong to the common defence and the general welfare. ${ }^{34}$

The Clause has been interpreted as providing Congress with absolute control over the public funds. ${ }^{35}$ Congress exercises this authority by making appropriations, which are by definition specific amounts of money set aside for designated purposes. ${ }^{36}$ It is not required to particularize each item in order for an appropriation to be valid, ${ }^{37}$ but

32. Exec. Order No. 11,652, 3 C.F.R. 339-50 (1974).

33. Id. at 339 . The policy of maximum disclosure was also instituted because the withholding of material which could be safely revealed undercut claims for the withholding of more sensitive material. Exec. Order No. 10,290, 16 Fed. Reg. 9798 (1951) (establishing an earlier version of the classification system). Justice Stewart has noted:

For when everything is classified, then nothing is classified, and the system becomes one to be disrcgarded by the cynical or the careless, and to be manipulated by those intent on self-protection or self-promotion. I should suppose, in short, that the hallmark of a truly effective internal security system would be the maximum possible disclosure, recognizing that secrecy can best be preserved only when credibility is maintained.

New York Times Co. v. United States, 403 U.S. 713, 729 (1971) (concurring opinion). See generally Rabi, The Cost of Secrecy, Atr. Monthly, Aug. 1960, at 41.

34.2 J. STORY, Commentaries on the Constitution of THE UNITEd STATEs $\$ 1348$, at 222-23 (5th ed. 1891) (emphasis added).

35. Ohio v. United States Civil Serv. Comm'n, 65 F. Supp. 776 (S.D. Ohio 1946); Burkhardt v. United States, $113 \mathrm{Ct}$. Cl. 658, 84 F. Supp. 553 (1949); Hart's Case, $16 \mathrm{Ct}$. Cl. 459, 484 (1880), aff'd, 118 U.S. 62 (1886) (" $[t]$ he absolute control of the moneys of the United States is in Congress, and Congress is responsible for its exercise of this great power only to the people').

36. Geddes v. United States, 38 Ct. Cl. 428, 444 (1903).

37. United States v. State Bridge Comm'n, 109 F. Supp. 690 (E.D. Mich. 1953). 
the appropriation must be sufficiently indentifiable to make clear the intent of Congress. ${ }^{38}$ Congress also has the authority to attach conditions to the use of funds appropriated for particular purposes. ${ }^{39}$

The first part of the Clause, requiring "appropriation made by law" before money issues from the Treasury, thus places an important responsibility in the Congress, the lawmaking branch of government. ${ }^{40}$ It allows Congress to control policy and to order priorities within the government as a whole and within each individual agency. To be effective in this task-to assure that there has been compliance with the appropriations laws it has passed, and that waste and corruption have been avoided-Congress would have to check how the Executive spent the appropriated funds. An accounting requirement running from the Executive to Congress may therefore be implicit in the first part of the Clause; Congress has in fact required reports from the Executive on almost all governmental spending. ${ }^{41}$

While there might be argument about a constitutional requirement that Congress be told how the money was spent, the second part of the Clause makes it clear that the information is to be released. The Constitution requires that the statement be "published"-made public -from time to time. ${ }^{42}$ While a regular statement would certainly be

38. Id. Thus a blanket appropriation to the Executive for all purposes of government, or an appropriation to the Office of Management and Budget (OMB) with the provision that $O M B$ had authority to transfer funds to other government agencies, might be open to challenge.

39. Ohio v. United States Civil Serv. Comm'n, 65 F. Supp. 776 (S.D. Ohio 1946). In Spaulding v. Douglas Aircraft Co., 60 F. Supp. 985, 988 (1945), aff'd, 154 F.2d 419 (9th Cir. 1946), the district court wrote:

Congress in making appropriations has the power and authority not only to desig-

nate the purpose of the appropriation, but also the terms and conditions under which

the executive department of the government may expend such appropriations....

The purpose of the appropriations, the terms and conditions under which said appropriations were made, is a matter solely in the hands of Congress and it is the plain and explicit duty of the executive branch of the government to comply with the same.

But see 50 U.S.C. $\$ 403 f(1970)$ :

In the performance of its functions, the Central Intelligence Agency is atthorized to-

(a) Transfer to and receive from other Government Agencies such sums as may be approved by the Office of Management and Budget, for the performance of any of the functions or activities authorized under Sections 403 and 405 of this title... Sums transferred.... may be expended... without regard to limitations of appropriations from which transferred...; and id. $\S 403 \mathrm{j}(\mathrm{b})$ :

The sums made available to the Agency may be expended without regard to the provisions of law and regulations relating to the expenditure of Government funds …

40. Youngstown Sheet \& Tube Co. v. Sawyer, 343 U.S. 579, 587-88 (1951).

41. See pp. 616, 617 infra.

42. That the Framers understood the significance in choosing the word "publish"meaning that the information would go to the people and not only to the Congress-is clear. Compare U.S. CoNsr. art I, $\$ 9$, cl. 7 ("a regular Statement and Account ... shall be published"), with id. art. II, $\S 3$ (The President "shall from time to time give to the Congress Information of the State of the Union..."). 
useful to a vigilant Congress, simply providing the information to the legislators is not sufficient. Moreover, the language is precise: The statement and account are to be "regular," and they must cover "all public Money." The second part of the Clause, then, was designed to make congressional responsibility "more perfect" 43 and allow the people to check Congress ${ }^{44}$ and the Executive through publication of information on what "money is expended, for what purposes, and by what authority." 45

Such information is useful for a number of reasons. The most obvious is that it allows the people to see the course of policy as reflected in governmental expenditures. The people could then determine for themselves whether too much money is being spent on defense, and too little on education, or whether too much money is spent on bombers as opposed to submarines. It allows the people, jointly with Congress, to determine if the expenditures by the Executive reflect the intent embodied in the appropriations. The information also provides an opportunity for the people to scrutinize appropriations by Congress and expenditures by the Executive to determine if they were for purposes allowed by the Constitution.46 Finally, on a somewhat more mundane level, the information allows the people, as Story put it, to detect "errors," uncover "misapplication of funds," and discover "corruption and public peculation," 47 supplementing the efforts of law enforcement officials charged with unearthing wrongdoing. If the people are dissatisfied with either

43. 2 J. STORY, supra note $34, \S 1348$, at 222-23.

44. See 2 J. Elliot, supra note 20, at 345 (statement of Chancellor Livingston):

You will give up to your state legislature everything dear and valuable; but you will give no power to Congress, because it may be abused; you will give them no revenue, because the public treastires may be squandered. But do you not see here a capital check: Congress are to publish, from time to time, an account of their receipts and expenditures. These may be compared together; and if the former, year after year, exceed the latter, the corruption will be detected, and the people may use the constitutional mode of redress.

45. $2 \mathrm{~J}$. STORY, supra note $34, \S 1348$, at 222-23. The reporting provision of Article I, $\$ 9$, Clause 7 might well come within the class of restrictions to which Justice Frankfurter was referring when he wrote: "The accretion of dangerous power does not come in a day. It does come, however slowly, from the generative force of unchecked disregard of the restrictions that fenced in even the most disinterested assertions of authority." Youngstown Sheet \& Tube Co. v. Sawyer, 343 U.S. 579, 594 (1951) (concurring opinion).

46. David Ramsey, one of the early commentators on the Constitution, wrote that if Congress applied any funds for purposes other than those set forth in the Constitution, they would have exceeded their powers. The clause provides information so that "[t]he people of the United States who pay, are to be judges how far their money is properly applied." Ramsey, An Address to the Freemen of South Carolina on the Subject of the Federal Constitution, in Pamphlets on the Constitution of the United States 374 (P. Ford ed. 1888). Without such information on expenditures, it would be impossible to mount the kind of challenge found in Flast v. Cohen, 392 U.S. 83 (1968).

47. $2 \mathrm{~J}$. STORY, supra note $34, \S 1348$, at 222-23. 
Congress or the Executive, based on the accounts required to be published, they will "use the constitutional mode of redress." $4 \mathrm{~s}$

\section{Government Funding and CIA Practices}

An examination of appropriations and accounting under Clause 7 since the adoption of the Constitution reveals a continuum of practices from full disclosure to strict secrecy. The most prevalent funding practice, however, one which dates from the first Congress, provides for specific appropriation and disclosure, in some detail, of how the money was expended. In 1791, the House provided by resolution that the Secretary of the Treasury bring before the House an "accurate statement and account of the receipts and expenditures of all public money," broken down by "each head of appropriation." ${ }^{9}$ "The text of the resolution makes clear that the report was to account accurately for all public money.

Most federal spending currently follows a standard procedure ${ }^{\square 0}$ which might be described as the full disclosure model. The Executive proposes a budget for the agency divided into a number of subappropriations by the program activities of the agency (the program classification budget) or by the object of the expenditure, such as personnel, or travel and transport (the object classification budget). The budget also provides for funds, if necessary, for plant and capital equipment. The appropriations committees of Congress then screen

48. $2 \mathrm{~J}$. Exlior, supra note 20 , at 345 (statement of Chancellor Livingston). It might be possible to argue that since the ballot is available as a sanction for abuse of the public treasury by either Congress or the Executive, it could also be used to discipline a Congress that failed to provide adequate information in the regular statement. Such a view of congressional accountability, while appealing as a study in direct democracy, ignores the particular form of checks and balances which the Constitution establishes; under the Constitution, no plebiscite on each congressional action is required. The Clause represents a determination by the Framers that certain information should be available to inform the debate that takes place at the time of elections. If the spending information is disclosed, debate foctuses on the merits of the spending rather than on the less gripping issue of a failure to disclose.

The position argued here certainly does not rest on an assumption that every voter will read the published accounts. Rather the information published there would be arailable to those citizens interested in a particular program or item, and through them would filter into the political process. Such filtering obviously cannot take place if the information is shut off at the source, and the public denied information which the Framers believed they had a right to know.

49. 2 ANNALS of CoNG. 302 (1792). The present provision is codified at 3 I U.S.C. $\$ \$$ $66 \mathrm{~b}, 1029(1970)$.

The "heads" of appropriation mentioned in the statute have been defined operationally for purposes of reporting-they simply are the agencies which have been appropriated funds and which therefore have a concomitant duty to account. A head of appropriation is thus a unit of arbitrary size, varying from a small commission to an agency receiving billions of dollars annually. Special provisions cover appropriations made for confidential purposes. See p. 617 infra.

50. See generally R. Fenno, The Power of THE PuRse (1966). 
the proposed budget, make recommendations, and bring them to the floor where Congress votes a specific appropriation to the agency. The resulting expenditures are subject to scrutiny by the congressional committees charged with substantive responsibility for the agency, by the Congress as a whole, and by the General Accounting Office (GAO), which serves as Congress's watchdog agency. ${ }^{51}$ Expenditures are described in the Combined Statement, ${ }^{52}$ the comprehensive account of government spending published pursuant to the requirements of the Clause. Proposed and actual appropriations and expenditures are reported in various other government publications, ${ }^{53}$ and more information is available to the public under the Freedom of Information Act. ${ }^{54}$

Since 1793 certain agencies have been appropriated funds specifically for confidential purposes; ${ }^{55}$ these agencies occupy the center of the disclosure continuum. ${ }^{56}$ For example, a foreign negotiation which requires secrecy might be funded from sums specifically appropriated to the State Department to be used for confidential purposes. Details of such expenditures are not published; their expenditure is accounted for by certification of the department head. ${ }^{57}$ The total budgeted for confidential purposes, as well as the total and details of nonconfidential funds, are still made public.58

51. See 31 U.S.C. $\$ 67(1970)$.

52. See, e.g., U.S. Dep'T OF Treasury, Combined Statement of Receipts, Expenditures, And Balances of the United States Government (1974) [hereinafter cited as Comibined STATEMENT].

53. The most important of these are the OMB's Budget and the Appendix to the Budget, which are published annually, and which have the appropriations proposed by the executive. Also available are the congressional hearings on the proposed appropriations, the reports of the congressional committees, and the debates on the floor of Congress.

54. 5 U.S.C. $\$ 552(1970)$, as amended, 1974 Amendments to the Freedom of Information Act, Pub. L. No. 93-502 (Nov. 21, 1974).

55. By the Act of February 9,1793 , Congress provided

that in all cases, where any sum or sums of money have issued, or shall hereafter issue, from the treasury, for the purposes of intercourse or treaty, the President shall be, and he hereby is authorized to cause the same to be duly settled annually with the accounting officers of the Treasury in the manner following, that is to say; by causing the same to be accounted for, specifically in all instances wherein the expenditures thercof may, in his judgment be made public; and by making a certificate or certificates, or causing the Secretary of State to make a certificate or certificates of the amount of stch expenditures as he may think it advisable not to specify; and every such certificate shall be deemed a sufficient voucher for the sum or sums therein expressed to have been expended.

Act of Feb. 9, 1793, ch. 4, $\$ 2,1$ Stat. 300 , codified as 3I U.S.C. $\$ 107(1970)$. That such a provision should be applied first to foreign negotiations is not surprising, given the almost universal concern on the part of the Framers for the integrity of foreign negotiations. See 2 J. Ellior, supra note 20 at $52 ; 3$ id. at $315-16 ; 4$ id. at $72-73$.

56. Sce, e.g., 31 U.S.C. $\$ 107$ (1970) (Dep't of State); 28 U.S.C. $\$ 537$ (1970) (Federal Bureau of Investigation); 42 U.S.C. $\$ 2017(b)$ (1970) (Atomic Energy Comm'n).

57. See notes 55,56 supra.

58. See, e.g., OMIB, APPENDIX to THE BUdget For Fiscal YeAr 1972, at 625, 860 (1972). 
The practices of the Atomic Energy Commission (AEC) provide a current example of this level of disclosure. Not only is the total budget of the AEC published, ${ }^{59}$ but the published budget also includes a breakdown for program activities such as "nuclear materials," "weapons," "reactor development," and "civil applications of nuclear explosives." 60 Within each of the program activities, the cost in major categories is set out: for example, in the 1973 budget for the nuclear weapons program, $\$ 400$ million was to be spent for production, $\$ 263$ million for research and development, and $\$ 109$ million for testing. ${ }^{61}$ Also published is the object classification budget ${ }^{62}$ and the plant and capital equipment budget. ${ }^{63}$ The total budgeted for "objects of a confidential nature," is likewise made public; it comes to $\$ 100,000$, a tiny part of the agency's entire budget. ${ }^{64}$

The funding and accounting practices for the CIA are situated at the secrecy extreme of the continuum. In a pattern which apparently developed only after World War $1 I^{65}$ virtually all of the funds ${ }^{66}$ which the CIA receives and expends are treated as confidential-as if they were for purposes which require secrecy-and the certificate of the Director serves as a sufficient accounting for their expenditure. ${ }^{87}$ Unlike the sums appropriated to the AEG and other agencies for objects of a confidential nature, however, CIA funds do not derive from a specific appropriation voted by the Congress. Rather the funds to be used by the CIA are concealed within the appropriations

59. OMB, APPENDIX to THE BUdGet for Fiscal YeAR 1973, at 771 (1973).

60. Id.

61. Id. at 772 .

62. Id. at 774 .

63. Id.

64. Id. at 771. Sufficient information about the AEC is published in the budget documents to allow the public to inform itself about relative priorities by comparing appropriations for the AEC with appropriations for the Department of Labor, or comparing spending for nuclear weapons with spending for peaceful applications of nuclear encrgy. Such information is absolutely crucial for evaluation and criticism of policy choices. Enough information may be available for a determination of whether funds are being expended for constitutional purposes. The published documents do not make available the vast quantity of information which would be necessary in order for the pcople to determine if congressional intent in, and conditions on, the appropriations have been complied with, and if extravagance and corruption have been minimized or eliminated; some of the information necessary for this is available through the provisions of the Freedom of Information Act, 5 U.S.C. $\$ 552$ (1970), as amended, 1974 Amendments to the Frecdom of Information Act, Pub. L. No. 93-502 (Nov. 21, 1974). On the difficulties of such an audit, see Catch-22, Newsweek, Apr. 22, 1974, at 88.

65. It does not appear that any agency was totally funded through secret transfer of funds or was completely secret in its accounting for expenditures prior to the end of World War II. See note 101 infra. At present not only the CIA but also the National Security Agency (NSA) make no public accounting. See note I44 infra.

66. The only official reference in the budget documents to CIA expenditures in the last several years has been the publication of appropriations and expenditures for construction. See, e.g., U.S. Der't of TREasury, CoMbined STATEMENT OF RECEIPTs, Expendtures, and Balances of THE UNited States Government 421 (1972).

67. 50 U.S.C. $\$ 403 \mathrm{j}(\mathrm{b})(1970)$, quoted in note 39 supra. 
proposed for other agencies in the President's budget proposal. The intelligence subcommittees of the appropriations committees examine the budget requests and determine the funding for the CIA. But neither the amount of the funds made available to the CIA nor their places of concealment in the budget are systematically disclosed to the full appropriations committees; there is disagreement over whether even the intelligence subcommittees of the armed services committees, which are supposed to monitor CIA activities, have access to full funding information. ${ }^{\text {ss }}$ After Congress passes the appropriations for those other agencies in which CIA funds are concealed, the funds for the CIA are secretly transferred by the Office of Management and Budget (OMB) to the CIA. ${ }^{69}$ The funds transferred are later reported as expenditures of the agencies to which the funds were originally appropriated..$^{70}$

Such practices must be judged a prima facie violation of the first part of the Clause. The CIA receives no specific appropriation; no clear statement of congressional intent can therefore be found. Instead, congressional intent in providing funds to one agency is actually negated by the transfer of those funds to the CIA without specific congressional authorization; the statute which provides for the administration of the CIA explicitly authorizes transfer "without regard to limitations" 71 in the original appropriation, as well as expenditure "without regard to the provisions of law and regulations relating to the expenditure of Government funds."72 Congressional authority to make policy and set priorities through the appropriations power is severely undercut.

The auditing procedure suggested by the second part of the Clause is also abrogated. Neither Congress nor the public can determine whether the expenditures comply with the CIA's enabling laws, ${ }^{73}$

68. Compare 117 CoNG. Rrc. 42924 (1971) (remarks of Sen. Symington), and N.Y. Times, Dec. 23, 1974, at 1, col. 8; Dec. 27, 1974, at 37, col. 1; Dec. 29, 1974, $\$ 4$, at 1, col. 5, with Lyman Kirkpatrick Talks About the CIA, Brown Alume MonTHLY, Nov. 1974, at 23, 29 [hereinafter cited as Kirkpatrick].

69. 50 U.S.C. $\$ 403 \mathrm{f}(\mathrm{a})(1970)$, quoted in note 5 supra.

70. Brief for Appellec (United States Government) at 3-1, Richardson v. United States, 165. F.2d 844 (3d Cir. 1972), rev'd, 94 S. Ct. 2940 (1974).

71. 50 U.S.C. $\$ 403 f(a)(1970)$, quoted in note 39 supra. If such a provision is valid, any congressional restriction on spending could be circumvented by transfer of both the funds and the responsibility for the activity to the CIA. See, e.g., Second Supplemental Appropriations $\lambda$ ct of 1973, l'ub. L. No. 93-50, \$ 307, 87 Stat. 129 (no Defense Dep't funds may, after Aug. 15, 1973, be used for combat activities in Cambodia, Laos, North Vietnam, and South Vietnam, or adjacent waters).

72. 50 U.S.C. $103 \mathrm{j}(\mathrm{b})(1970)$, quoted in note 39 supra.

73. For example, it was revealed in the press that the CIA had assisted with the training of local police in violation of the injunction in the National Security Act of 1947, $\$$ $102(d)(3), 50$ U.S.C. $\$ 403$ (d)(3) (1970), against the CIA's involvement in domestic security operations. N.Y. Times, Feb. 6, 1973, at 1, col. 1; Marchetti \& Marks, supra note 4, at 224-25. The concern with the possibility of CIA involvement in domestic affairs was clearly 
or with the Constitution, ${ }^{74}$ and whether they have been made without waste $^{75}$ or corruption. ${ }^{70}$ Neither Congress nor the public can weigh CIA spending against that of other agencies; the CIA's internal ordering of priorities cannot be analyzed. Because the funds transferred to the CIA can come from any government agency, ${ }^{77}$ the Congress and the public cannot with assurance accept the account covering any government agency as the regular statement and account the Constitution requires.

The system might be more palatable (even though its prima facie unconstitutionality would not be affected) if the public could have greater confidence in the virtual delegation to the appropriations subcommittees and the OMB of the authority to appropriate funds, ${ }^{78}$ and to the armed services subcommittees of the task of overseeing the CIA's activities. Substantial evidence has surfaced in recent years, however, that the congressional subcommittees and committees in-

demonstrated at the hearings on the National Security Act of 1947. Representative Brown told the House Armed Services Committee,

I would want to make certain that the activities and functions of the Central Intelligence Agency were carefully confined to international matters, to military matters, and to matters of national security. We have enough people running around butting into everybody's business in this country without establishing another agency to do it. What we ought to do is to eliminate 90 percent of the present snoopers instead of adding to them.

Congressman Dorn added,

The Central Intelligence Agency is primarily concerned and almost entirely concerned with intelligence pertaining to military and foreign matters. I tell you, the crowd you have to worry about is the FBI and Tom Clark.

Hearings on the National Security Act of 1947 Before the House Comm. on Armed Services, 80th Cong., Ist Sess. $438-39$ (1947). As a result of this concern the National Security Act of 1947 forbids the CIA from exercising any "police, subpoena, law enforcement powers, or internal-security functions." On the secrecy of CIA domestic operations, see MarchetTI \& MARKs, supra note 4, at 224-29; N.Y. Times, Dec. 29,1974 , $\$ 1$, at 1, col. 1 .

It has also been alleged that the CIA was engaged in a massive domestic intelligence operation, including surveillance of members of Congress and the Supreme Court. See N.Y. Times, Dec. 22, 1974, $\$ 1$, at 1 , col. 8; Dec. 25,1974 , at 1 , col. 8; Dec. 29, 1974, $\$ 1$, at 1, col. 1; Dec. 30, 1974, at 1, col. 3; Wash. Post, Dec. 25, 1974, at A 1, col. 6, 8; Rattling Skeletons in the CIA Closet, TIME, Jan. 6, 1975, at 44.

74. See Appellant's Brief at 4, A12, Richardson v. United States, 465 F.2d 844 (3d Cir. 1972), rev'd, 94 S. Ct. 2940 (1974).

75. See A. Tully, The Super Spies 232 (1969); 117 Conc. Rec. 40283-84, 42923-26 (1971) (remarks of Sen. Symington). See generally MARCHETII \& MARks, supra note 4, at 58-59, 96-101, $278(1974)$.

76. See MaRchetri \& Marks, supra note 4, at 147.

77. See 50 U.S.C. $\$ 403 f(a)(1970)$. Lyman Kirkpatrick has suggested, however, that the CIA's funds are hidden in the procurement section of the Department of Defense appropriation. Intervicw with Lyman Kirkpatrick, former CIA Executive Director-Comptroller, in Bristol, R.I., Dec. 6, 1973 (tape of interview on file with the Yale Law Journal). See generally N.Y. Times, Dec. 29, 1974, $\$ 4$, at 1, col. 5 .

78. See 50 U.S.C. $\$ 403 \mathrm{f}(\mathrm{a})(1970)$. It is useful to remember what Justice Brennan wrotc in United States v. Robel, 389 U.S. 259, 276 (1967) (concurring opinion);

Formulation of policy is a legislature's primary responsibility, entrusted to it by the electorate, and to the extent Congress delegates authority under indefinite standards, this policy-making function is passed on to other agencies, often not answerable or responsive in the same degree to the people..."Without explicit action by lawmakers, decisions of great constitutional import and effect would be relegated by default to administrators, who, under our system of government, are not endowed with authority to decide them." Greene v. McElroy, 360 U.S. 474, 507. 
volved have been ineffective in exercising their supervisory authority. ${ }^{79}$ The thoroughness of the OMB's monitoring has been subjected to similar criticism. ${ }^{80}$

\title{
IV. Possible Means of Reconciling the CIA Funding Practice with the Clause
}

\author{
The current CIA funding practices clash with the apparent re- \\ quirements of the Clause. Nonetheless, there are several theories
}

79. The subcommittees do not have the assistance of the GAO to help monitor all CIA cxpenditures, but "[i]ntelligence officials insist... that... funds are audited just as stringently." H. Ransom, The Intelligence Establishment 87 (1970). President Eisenhower told Allen Dulles to make sure that CIA internal auditing procedures were even more searching than those of the GAO, A. Dulles, The Crafr of INTElligence 259 (1963). A 1955 Hoover Commission study noted, however, that the lack of outside surveillance raised "the possibility of the growth of license and abuses of power where disclosure of costs, organization, personnel, and functions are precluded by Law." Quoted in $\mathrm{H}$. RANSOM, supra, at 161 .

Senator Symington, a member of the Intelligence Subcommittee of the Armed Services Committee, has strongly criticized its work. See N.Y. Times, Dec. 23, 1974, at 1, col. 8; 117 CoNG. REC. 42924-26 (1971). Symington noted that the subcommittee had not met at all in 1971. Id. at 42931 . The subcommittee has met twice this year. N.Y. Times, Dec. 29, $1974, \S 4$, at 1 , col. 5. Representative Norblad, a former member of the Intelligence Subcommittee of the Armed Services Committee, stated that it met annually for two hours. D. Wise \& T. Ross, The INvisible Government 265 (1964). That subcommittee met six times in 1974. N.Y. Times, Dec. $29,1974, \$ 4$, at 1 , col. 5. See generally N.Y. Times, Dec. 27,1974 , at 37, col. 1; Dec. 10, 1974, at 15, col. 1; MARCHETTI \& MARKs, supra. note 4, at 323,342 . It should be noted that in the future the House Foreign Affairs Committee will share jurisdiction over foreign policy related activities of the CIA. Wash. Post, Dec. 24, 1974, at A 9, col. 8 .

If the supervision by the armed services subcommittees is cursory, the burden of congressional supervision falls on the intelligence subcommittees of the Senate and House Appropriations Committees. The appropriations subcommittee in the Senate is made up of the most senior members of the Committee; the membership of the subcommittee in the House is secret. R. Fenno, supra note 50, at 131 n.6. Marcherti \& Marks, supra, at $345-47$, criticize the procedures of the appropriations subcommittees and note that in 1967 the CIA did not even appear before the budgetary oversight subcommittees. The Senate subcommittee met five times this year. N.Y. T imes, Dec. $29,1974, \$ 4$, at 1, col. 5 . One exchange on the floor of the Senate calls into question that subcommittee's work. In response to Symington's criticism of CIA activities in Laos and to Cranston's questions, it was revealed by Ellender that neither he nor the Intelligence Subcommittee of the Senate Appropriations Committee had known anything about the CIA's employment of mercenaries in Laos before reports appeared in the press. After reading the reports, neither sought further information from the CIA. 177 CoNG. REc. 42929-31 (1971).

Lyman Kirkpatrick, who strongly disagrees with Senator Symington's assessment of the amount of control exercised over the CIA, MARCHETr 321, nonetheless has suggested that effective oversight by Congress would require two or three working days per month. $L$. Kirkpatrick, The ReAl CIA 273 (1968). See generally P. McGarvey, THE CIA 216 (1972). There is some question as to the ability of Congress to supervise the CIA, no matter how much time is spent, when it is not clear that the CIA Director will always respond candidly to questions posed by members of Congress. See N.Y. Times, Nov. 23, 1974, at 14, col. 3; MarchetTI \& MaRks, supra, at 228-29.

80. In the absence of any checking by the GAO, the OMB might supplement the internal audits of the CIA. The OMB, however, has only five employees monitoring the budgets and expenditures of the entire intelligence community, of whom only one examiner (along with the branch chief) scrutinizes the CIA's budget. Marchetri \& Marks, supra note 4, at 336. But see Kirkpatrick, supra note 68 , at 29 . Richard Helms, former Director of the CIA, has maintained that the budget is gone over line-by-line by the OMB. MARChEITI \& MARKs, supra, at 339. Marchetti and Marks, however, describe the OAIB as usually "indulgent" to the CIA; they allege that the CIA works hard at concealing its activities and any surplus funds from the OMB. Id. at 62, 337-39. 
which Congress and the Executive might use to argue that the practices satisfy the Clause. Room might be found within the phrase "from time to time." Congress's authority over the detail to be included in the Combined Statement might authorize the practice. The secrecy might find some support in Congress's acknowledged power to withhold certain proceedings from publication in its journals, or it might be considered a longstanding practice and therefore presumed constitutional. This section evaluates each of these contentions and finds them wanting.

\section{A. "From Time to Time"}

One line of justification asserts that the Framers' choice of the phrase "from time to time" 81 in place of a requirement for annual publication was designed to provide secrecy for sensitive expenditures. Under this theory, such expenditures would be revealed as the need for secrecy disappeared.

In the debates on Clause 7 , the need for secrecy was mentioned briefly. At the Virginia Convention, Mason, who had fought for annual statements, stated that the need for secrecy was among the reasons which had been suggested for the adoption of the ambiguous phrase "from time to time."s2 $\mathrm{He}$ did not indicate who had suggested this reason nor do the recorded debates note any such suggestion. Mason and other opponents of "from time to time" did fear that the "looseness" of the phrase might allow a decision not to publish any account. It might "afford opportunities of misapplying the public money, and sheltering those who did it" by allowing expenditures to be "concealed forever." 83 Madison argued against Mason's position not because of the need for secrecy but because

if the account of the public receipts and expenditures were to be published at short stated periods, they would not be so full and connected as would be necessary for a thorough comprehension of them, and detection of any errors. But by giving them an opportunity of publishing them from time to time, as might be found easy and convenient, they would be more full and satisfactory to the public, and would be sufficiently frequent. ${ }^{84}$

81. This phrase was used several times in the Constitution, and has come to represent different time intervals. See U.S. CoNST. art $1, \S 5, \mathrm{cl}$. 3 (providing for the journals of Congress); id. art. II, $\S 3$ (providing for the State of the Union message). The Combined Statement, supra note 52, published pursuant to Clause 7 and to 31 U.S.C. $\$ \$ 66 \mathrm{~b}, 1029$ (1970) is issued annually, as is the State of the Union Message; a daily edition of the Congressional Record is available.

82. D. RoberTson, supra note 20 , at 326.

83. Id.

84. Id. at $326-27$. 
If the need for secrecy were indeed the reason for adopting Madison's phrase, it is striking that such a need was not raised in the debates by any of the proponents; they suggested that the phrase meant short, convenient intervals, ${ }^{85}$ and they justified it on the basis that it would provide fuller information to the public. The proponents appear to have agreed with Mason, who stated that he did not "conceive that the receipts and expenditures of the public money ought ever to be concealed." 86 Basing the decision never to reveal CIA expenditures on the phrase "from time to time," then, would run counter to the explanations of the phrase offered at the conventions by its supporters, and would confirm the worst fears of the opponents of the phrase, fears that were dismissed by the proponents as groundless. ${ }^{57}$ It would also ignore the fact that the phrase has since been determined by Congress uniformly to require other agencies to report annually.

\section{B. Congressional Control over the Form and Content of the Accounts}

It has been argued that Congress has plenary power over the form and content of the accounts ${ }^{88}$ and could decide therefore to provide no information on the expenditures of the CIA. This argument seems to read the Clause as relating only to a division of power between the Congress and the Executive. Perhaps the first part of the Clause has that purpose; it places the appropriations power squarely in the Congress and implies reporting by the Executive to Congress. But the second part requires that a regular statement be published-presented to the public. It was designed to allow the people to check not only the Executive but also the Congress. ${ }^{89}$ If Congress possessed absolute authority over the inclusion or exclusion of information, this check would be rendered meaningless.

85. See note 22 supra.

86. D. ROBERTSON, supra note 20 , at 326 .

87. See note 22 supra. It might be possible to argue that, while reports of CIA expenditures need not be withheld forever, they might constitutionally be withheld for a period which would ensure that their revelation would not damage the national security, e.g., for a period of 10,15 , or 20 years. While such a practice might be justified under an expansive interpretation of "from time to time," it finds no support in the debates and there are serious questions whether the publication of expenditures, either in lump sum or in detail, poses any reasonable threat to national security. See pp. 632-33 infra.

88. Although we do not reach or decide precisely what is meant by a regular statement or account, it is clear that Congress has plenary power to exact any reporting and accounting it considers appropriate in the public interests.

United States v. Richardson, 94 S. Ct. 2940,2947 n.11 (1974).

89. Sce notes 43-45 supra; United States v. Richardson, 94 S. Ct. 2940, 2956 (1974) (Douglas, J., dissenting). 
While the Framers did not describe in detail what the regular statements were to include, the debates do indicate that the reports were to be "full," "not too general," connected enough for a "thorough comprehension," but not so detailed as to be "impracticable." 90 No mention was made of Congress's power simply to exclude an agency from the reports.

Congress therefore does have some power over the content and form of the accounts. But to provide almost no information whatsoever on the expenditures of a large and important agency is hardly a mere decision on detail; especially when inclusion would be practicable and would increase comprehensibility, and when the transfer procedures make suspect all other reported expenditures.

\section{Congressional Control over the Journals}

The Constitution provides that each house keep "a Journal of its Proceedings and from time to time publish the same, excepting such Parts as may in their Judgment require Secrecy . . . ."91 Since Congress thus has the power to withhold from the public the congressional debates on the matters for which money is being appropriated, some have suggested that it would be inconsistent to assume an intention on the part of the Framers to provide an absolute obligation to publish every expenditure. ${ }^{92}$ But the two constitutional provisions are not equivalent. ${ }^{93}$ There is an explicit provision for secrecy in the Journal Clause; ${ }^{94}$ there is no such provision in the Statement

90. See note 18 \& p. 622 supra.

91. U.S. Const. art. I, $\$ 5, \mathrm{cl} .3$.

92. Appellant's Brief to the Supreme Court at 24-25, United States v. Richardson, 94 S. Ct. 2940 (1974).

93. In the course of the Virginia debates, Madison did imply that the journal was to include the statement of accounts. See note 96 infra. Patrick Henry apparently also believed that the regular statement would be included in the journal. He opposed the wide exception to publication in the journal and the ambiguity of "from time to time" because these provisions would "allow the national wealth ... to be disposed of under the veil of secrecy." $3 \mathrm{~J}$. ElLIOT, supra note 20 , at 462.

The Constitution is not explicit as to whether the accounts must be published in the journal or in a separate document. Under the Articles of Confederation a journal was published monthly; until publication ceased, the accounts were published semi-annually. Given the differences in history and in content, and the fact that the provisions for a journal and a regular statement appear in different sections of the Constitution, the apparent belief of some of the Founders that one would include the other does not compel a conclusion that the Constitution requires inclusion nor that the journal secrecy was meant to apply to the accounts. Moreover, Congress has consistently provided for separate publications.

94. The congressional power to withhold the debates from publication was discussed thoroughly during the discussions on Article $I, \S 5$, clause 3 . The original proposal made no provision for journal secrecy. After the broad secrecy provision ultimately passed was added, there were several unsuccessful attempts to narrow the exception to one similar to that provided in the Articles of Confederation, article IX. See 2 Records, supra note 9 , at 180, 260; $3 \mathrm{~J}$. Ellior, supra note 20, at 403 . 
and Account Clause. Rather the latter clause emphasizes regular accounting of all public money. The difference in plain language would seem to be a strong argument against this ground for nondisclosure of CIA expenditures.

In addition, the proceedings of Congress which were to be reported in the journal contained discussions of foreign negotiations and alliances, treaties not yet come to maturity, and possible military operations, the revelation of which the Framers feared. ${ }^{95}$ The Framers believed that the amount of detail which was to be included and which was necessary to accomplish the purposes for which the regular statement was established would not compromise these vital interests. ${ }^{96}$

\section{Longstanding Practice}

It might also be suggested that the CIA's funding secrecy cannot be called into question because it is a practice of long standing. Longstanding practice is not, in itself, a justification for practices which are unconstitutional.97 Rather longstanding practice provides a "gloss" which aids in the interpretation of the Constitution;" longtime acceptance of a practice without attack may establish a form of presumption of the constitutionality of the practice. ${ }^{99}$ Since the funding and budget disclosure provisions for the CIA have gone unchallenged from 1947 until recently, it might be contended that their constitutionality is presumed. However, 27 years hardly mean that the practice is sufficiently well established to claim the benefit of the doc-

95. See 2 J. Elliot, supra note 20 , at $52 ; 3$ id. at $315-16 ; 4$ id. at $72-73$; D. ROBERTSON, supra note 20, at 236; cf. Exec. Order No. 11,652, 3 C.F.R. 339 (1974).

96. A specch by Madison to the Virginia Convention supports this conclusion. Defending the journal secrecy provision, he stated that "the policy of not divulging the most important transactions, and negotiations of nations, such as those which relate to warlike arrangements and treaties, is universally admitted." D. RoBERTsoN, supra note 20, at 236. He assured the Convention, however, that, "the Congressional proceedings are to be occasionally published, including all receipts and expenditures of public money, of which no part can be used, but in consequence of appropriations made by law." Id. (emphasis in original). He thereby implied that, despite possible inclusion in the journals, the constitutionally required accounts would not fall within the secrecy exception. See p. 623 supra.

97. Youngstown Sheet \& Tube Co. v. Sawyer, 343 U.S. 579, 610 (1952) (Frankfurter, J., concurring).

98. Id. at 610-11.

99. As Chief Justice Burger wrote:

Not controlling, but surely not unimportant are nearly two centuries of acceptance of a reading of cl. 7 as vesting in Congress plenary power to spell out the details of precisely when and with what specificity Executive agencies must report the expenditure of appropriated funds and to exempt certain secret activities from comprehensive public reporting.

United States v. Richardson, 94 S. Ct. 2940, 2947 n.11 (1974). 
trine, ${ }^{100}$ especially when compared to the practice of disclosure which dates from 1791.

One might still respond that the practices of the CIA are simply examples, albeit somewhat more extreme, of congressional provisions for confidential expenditures. Since 1793 details of expenditures from appropriations made for confidential purposes have been withheld, but Congress always made a specific appropriation, and such appropriations were never for the entire budget of an agency. In many cases, information on the use made of those funds has been revealed shortly after the expenditure, ${ }^{101}$ or if withheld, would be available to Congress under certain conditions. ${ }^{102}$ CIA practice thus departs too drastically from earlier practices to claim them as precedent. ${ }^{103}$

100. See generally Youngstown Sheet \& Tube Co. v. Sawyer, 343 U.S. 579, 611, 613 (1952) (Frankfurter, J., concurring).

101. See, e.g., D. Miller, Secret Statutes of the United States (1918) (discussion of funds secretly, but specifically, appropriated in 1811 and 1812 which were used for the occupation of Florida; the use of these funds was revealed in 1818). The most famous example of secret funding was the Manhattan Project. Details of the arrangements to fund the development of the atomic bomb were revealed immediately after World War II. See I. Groves, Now It CAN BE Told 361 (1962). In the case of the Manhattan Project funds were provided through appropriations to "Engineering Service: Army" and "Expediting Prosecution of the War Effort" with the true use of funds known only to the congressional leadership. Representatives Martin, Rayburn, and McCormack, apparently without statutory authority, agreed to a plan whereby they would be given advance notice of the Manhattan Project's funding requirements and the places in the budget where the funds would be concealed. Selected members of the appropriations committees were to be told that these budget items had been discussed with the Secretary of War and should not be questioned. Id. at 360,363 . Other committee members and the other members of Congress would only be given general information about these items.

The large expenditures in "Engineering Service: Army" and "Expediting Prosecution of the War Effort" did not entirely escape congressional notice. A Special Senate Committee on the National Defense, headed by Harry $S$. Truman, sought to investigate them, but agreed to postpone the investigation until security permitted. Id. at 365 .

Senator Millard Tydings remembered the funding in a different way. "General Marshall came before the Appropriations Committee one day and said in effect this:

Gentlemen, I want you to give me a billion dollars. I do not want you to ask me what it is going to be used for. It is a military secret, but I hope you will give me the money."

The Committee responded, to the recollection of Tydings, by asking whether a billion dollars would be enough. Hearings on the National Security Act Before the Senate Comm. on Armed Services, 80 th Cong., lst Sess., pt. 2, at 623 (1947).

While appropriations for the Project were concealed from Congress and the people, the justification offered was that concealment was a wartime necessity, preventing German discovery of our development of this new weapon. See note 130 infra. The project was under Army supervision; the funds were thus never transferred to a separate agency. The funds were a small part of the Army budget-a budget which was available even in wartime. Finally, as the Comptroller General told the Senate Special Committee on Atomic Energy, he and his staff had audited or were auditing every single penny expended on the Project. L. Groves, supra at 361 .

102. For example, details of expenditures by Daniel Webster from a discretionary fund were made available to the Senate by former President Tyler in 1846, when such cxpenditures came under investigation. See Dorsen \& Shattuck, Executive Privilege: The President Won't Tell, in NONE OF Your Business: GovernMeNT SECRECY IN AMERICA 56 (N. Dorsen \& S. Gillers ed. 1974).

103. It might also be argued that congressional practice since 1791 has been to appropriate money to, and require reports from, separate heads of appropriation (see note 49 supra). As the CIA does not constitute a head of appropriation-is not appropriated 


\section{The National Security Justification}

The preceding section has demonstrated that alternative interpretations which would reconcile present CIA funding practices with Clause 7 are simply not convincing. Nonetheless, the requirements of the Clause are not absolute; if fulfilling them would endanger the national security, they would have to yield or at least be redefined. But the mere fact that national security is invoked does not close the question. ${ }^{104}$ In the past when national security claims have been raised in support of particular congressional actions, the Court has not allowed them simply to override, without analysis, constitutional requirements or guarantees; ${ }^{105}$ the claims have been analyzed using various tests which the courts have fashioned. ${ }^{106}$

funds-it might be argued that the requirement for an account broken down by each separate head of appropriation does not apply to it. Under this interpretation, the funds which it receives are accounted for sufficiently under the expenditures reported by the agency which originally received the appropriation.

If this mechanical reading of the longstanding practice were to prevail, Congress could by statute reduce reporting to a single head, i.e., appropriate all funds to the OMB and have all funds reported as expended by the OMB. This would satisfy the congressional requirement for accounting by head of appropriation, but it would probably violate the first part of the Clause, and it would render the second part of the Clause meaningless. The "head of appropriation" requirement would be applied more logically if the CIA were required to report as a "functional" head of appropriation because money, through not appropriated to it, is set aside and transferred to it.

104. The importance of the Clause should not be minimized even when national security intercsts are involved. Justice Stewart wrote:

In the absence of the governmental checks present in other areas of our national

life, the only effective restraint upon executive policy and power in the area of na-

tional defense and international affairs may lie in an enlightened citizenry.

New York Times Co. v. United States, 403 U.S. 713, 728 (1971) (concurring opinion).

105. See, e.g., New York Times Co. v. United States, 403 U.S. 713 (1971); Alderman v. United States, 394 U.S. 165 (1969).

106. The courts have not settled on any one test; even where arguable individual rights have been at issue, court treatment has ranged from demanding inquiry to an almost passive acceptance of the government's claim of a national security threat. Compare New York Times Co. v. United States, 403 U.S. 713, 726-27 (1971) (Brennan, J., concurring) ("only governmental allegation and proof that publication must inevitably, directly, and immediately cause the occurence of an event kindred to imperiling the safety of a transport already at sea can support even the issuance of an interim restraining order."), with Zemel v. Rusk, 381 U.S. 1 (1965) (upholding passport restrictions against travel to certain countries as supported by the "weightiest considerations of national security," with little further analysis). Of the latter decision, recent commentary noted that "[ $t]$ he Court... failed to analyze carefully those [considerations]. Such an analysis would have revealed that rather limited foreign policy interests are served by the system of area restrictions." Note, Developments in the Law-The National Security Interest and Civil Liberties, 85 Harv, L. Rev. 1130 , 1149 (1972).

A recent revision of the classification guidelines illustrates subtle but important differences in standards that could be used. The previous system authorized top secret classification for material "the unauthorized disclosure of which could result in exceptionally grave danger to the Nation..." Exec. Order No. 10,501, 3 C.F.R. 115 (Supp. 1953), $18 \mathrm{Fed}$. Reg. 7049 (1953) (emphasis added). The new test is "whether... unauthorized disclosure [of the information] could reasonably be expected to cause exceptionally grave danger to the national security." Exec. Order No. 11,652, 3 C.F.R. 340 (1974) (emphasis added). Examples of "exceptionally grave danger" are provided in both Executive Orders. The latter lists: "armed hostilities against the United States or its allies; disruption of foreign relations vitally affecting the national security; the compromise of vital defense 
In United States $v$. Robel, ${ }^{107}$ the Court was called upon to assess the constitutional validity of a congressional act which its proponents justified on the grounds of national security. It found the act unconstitutional; Chief Justice Warren, writing for the Court, summed up the test:

[W]e have confined our analysis to whether Congress has adopted a constitutional means in achieving its concededly legitimate legislative goal. In making this determination we have found it necessary to measure the validity of the means adopted by Congress against both the goal it has sought and the specific prohibitions of the First Amendment. . . . We have ruled only that the Constitution requires that the conflict between congressional power and individual rights be accommodated by legislation drawn more narrowly to avoid the conflict. ${ }^{108}$

Robel involved First Amendment rights. But one need not believe that the Clause has the preeminent status accorded the First Amendment, nor that the rights it grants are individual rights, in order to accept a test similar to Robel's for analyzing apparent violations. The Clause sets forth a clear constitutional requirement in plain language in the text of Article I. Congress should be expected, in the legislation it passes, to minimize potential conflict with explicit provisions of the Constitution, whether those provisions be found in the Bill of Rights or elsewhere. It therefore makes sense

plans or complex cryptographic and communications intelligence operations; and the disclosure of scientific or technological developments vital to national security." Id. For a discussion of the justiciability of such standards, see Nimmer, National Security Secrets $v$. Free Speech: The Issues Left Undecided in the Ellsberg Case, 26 STAN. L. REv. 311, 328 n.80 (1974).

The important variables in any test are therefore the seriousness of the expected cffects of disclosure and the likelihood that disclosure will have such a result. A related question involves the respective roles of the courts and the Executive in assessing both likelihood and seriousness. See New York Times Co. v. United States, supra, at 757 (Harlan, J., dissenting) ("In my judgment the judiciary may not properly... redetermine for itself the probable impact of disclosure on the national security."). But see N.Y. Times, Nov. 22, 1974 , at 21, col. 3 (1974 amendments to the Frcedom of Information Act mandate court review of executive classification decisions).

Under a loose test of the national sccurity claim-for example, whether revealing the information could conceivably have some negative impact on national security-cven budget information on the interstate highway system could be withheld. Government expenditures on interstate highways have an arguable effect on national security. See Federal-Aid Highway Act of 1956 , ch. $462, \$ 108(\mathrm{a}), 70$ Stat. 378 ("Because of its primary importance to the national defense, the name of such system is hereby changed to the 'National System of Interstate and Defense Highways." )

Given the purposes of the Clause, any standard which allowed such secrecy could not be tolerated. This Note recommends a standard based upon consequences one "could reasonably expect"; concealment via appropriation for confidential purposes should not be allowed unless the expected risk is substantial, and courts should not rest solely upon executive assertion but should examine the circumstances themselves.

107. 389 U.S. 259 (1967).

108. Id. at 268 n.20. 
to give detailed consideration, as Robel did, to the exact goal Congress has sought, the ways in which the act in question is supposed to serve the goal, the impact the act has on constitutional requirements, and possible alternatives for achieving the congressional goal.

By establishing the CIA, Congress sought to promote the gathering. of foreign intelligence information, a concededly valid legislative goal. The agency is to advise the National Security Council on intelligence matters, to correlate and evaluate intelligence materials for the Council, and to perform other intelligence-related tasks. ${ }^{109}$ What must be examined is how the funding arrangements are related to the accomplishment of that goal, for their effect on the constitutional requirements of the Clause is clear: The appropriations requirement and the reporting requirement are both violated, to the point where they are almost rendered meaningless. An examination of the legislative history of the CIA $\mathrm{Act}^{110}$ may make it clear why Congress enacted these funding provisions, exactly what aims it sought to secure, whether alternatives were considered, and how Congress interpreted the requirements of the Clause.

The first legislative provisions for the CIA were provided by the National Seccirity Act of $1947 . .^{111}$ Secrecy for the CIA budget was touched upon at two points in the congressional hearings. Allen Dulles recommended a separate appropriation for the CIA as well as a provision for supplemental funding from other agencies in order to carry out special operations. It might be inferred that secret funds for these operations would be desirable, but he did not urge a completely secret budget. ${ }^{112}$ Later in the hearings an officer of the Reserve Officer's Association recommended a classified, budget. ${ }^{113}$ Congress did not act on either recommendation; it waited two years to provide an administrative blueprint for the CIA.

The 1949 bill provided for secret funding by transfer from other agencies. The Congress was told that almost all of the provisions of the bill already existed for other government agencies and were merely being extended, ${ }^{114}$ but no precedent for the funding or re-

109. 50 U.S.C. $\$ 403(1970)$.

110. Id. It is difficult to feel confident about any analysis of the CIA's legislative history due to the amount of material still classified. It has been alleged that certain secret protocols about the CIA were agreed to in 1947. See N.Y. Times, Dec. 26, 1974, at 46, col. 4.

111. Act of July 26, 1947, ch. 343, \$ 102, 61 Stat. 497 .

112. Hearings on $S .758$ Before the Senate Comm. on Armed Services, 80th Cong., 1st Sess. 528 (1947) [hereinafter cited as Nat'l Defense Hearings].

113. Id. at 550 .

114. 95 CoNG. REc. 1944 (remarks of Rep. Sasscer), 1948 (remarks of Rep. Vinson) (1949). The principal exception, the one power which apparently was being given the CIA alone, was the authority to admit a limited number of aliens without regard to the immigration laws. See id. at 1945 (remarks of Rep. Celler). 
porting provisions was set forth in the hearings, reports, or floor debates. ${ }^{115}$

The debates in the House made clear that the funding provisions had been in use since the CIA's creation without congressional authorization, ${ }^{116}$ that the CIA Act would "legalize" this method of funding, ${ }^{117}$ that such a method was the only way to operate the agency efficiently without impairing security, 118 and that it would not be "wise" to disclose the CIA's budget."119 No one suggested the existence of a constitutional requirement to publish appropriations and expenditures; the possibility of publishing parts of the CIA's budget was not raised.

Discussion of the funding arrangements was more extensive in the Senate, ${ }^{120}$ though the floor managers were very concerned that too much information was being made public in the debate. ${ }^{121}$ One Senator questioned the bypassing of the traditional procedure of making specific appropriations to specific agencies; ${ }^{122}$ he was assured that while such procedures were fitting for normal governmental functions, if they were followed for the CIA they might result in the capture and death of CIA agents. ${ }^{123}$ The Senate was told that every

115. Most of the hearings were in executive session. The unclassified sections of the hearings do not aid the analysis. As Chairman Vinson put it:

We will just have to tell the House they will have to accept our judgment and we cannot answer a great many questions that might be asked. We cannot have a Central Intelligence Agency if you are going to advertise it and all of its operations from the tower-what is the big building in New York?

Congressman Short: "The Empire State."

Hearings on H.R. 1741, H.R. 2546 H.R. 2663 Before the House Comm. on Armed Services, 81st Cong., lst Sess., ser. 26, at 487 (1949). The House committee report only summarized the bill's provisions for fear of compromising security. H.R. REP. No. I60, 8lst Cong., 1st Sess. 5 (1949).

The failure to provide detailed explanations caused considerable controversy. Representative Marcantonio told the House that

the Committee informs us through its report that the Members of the House must pass this bill without any explanation of all its provisions. This makes every single section of the bill suspect.... There has never been and there can never be any justification, at any time, for the representatives of the people...t to abdicate their functions.

95 CoNc. Rec. 1946 (1949) (remarks of Rep. Marcantonio).

The most similar previous funding arrangement, that for the Manhattan Project, see note 101 supra, was not cited as precedent for the funding arrangements, although it was raised briefly in other contexts. See 95 CoNG. REc. 1947 (remarks of Rep. Marcantonio \& Rep. Short), 6955 (remarks of Sen. M. Tydings) (1949).

116. 95 CoNG. REC. 1949 (1949) (remarks of Rep. Vinson).

117. $I d$.

118. Id.

119. Id.

120. See id. at 6955 (remarks of Sen. McKellar \& Sen. M. Tydings).

121. Id. at 6952 (remarks of Sen. M. Tydings).

122. Id. at 6955 (remarks of Sen. McKellar).

123. Id. (remarks of Sen. M. Tydings). Senator Tydings's remarks seem directed not at budgetary disclosure or specific appropriations, but rather at disclosure of personnel or the public availability of pay vouchers. 
democratic safeguard was being put around the CIA. ${ }^{124}$

The bill passed and was signed by the President. The failure of the congressional committees to provide detailed information on the legislation, the absence of cited precedents for the funding provisions, and the lack of discussion about the requirement for an accountingall create considerable uncertainty whether Congress carefully analyzed the requirements of national security, the procedures necessary for the successful operation of the CIA, and the commands of the Clause.

The one reason plainly asserted for the provision was the safety of American intelligence agents. ${ }^{125}$ But the necessity of guaranteeing the safety of covert agents should not lead one to ignore the fact that a large majority of the estimated 16,500 employees of the CIA work in the United States. ${ }^{120}$ Moreover, even during the immediate post-war period the vast bulk of the intelligence collected was obtained from overt sources. ${ }^{127}$ Although other goals were not mentioned in the reported congressional deliberations on the CIA Act, the provisions might have been enacted to protect the security of CIA tactical operations, ${ }^{128}$ to prevent disclosure of past operations, ${ }^{129}$ or to keep secure technological advances such as the development of new weapons. ${ }^{130}$

124. Id. Senator Tydings also told the Senate:

I think it is a question whether or not the law is being winked at unless this bill is written into law. It is written to effect a cure. It is a question as to whether we have the authority to act. In my opinion we have not the authority, but nobody is going to raise the question.

Id. It appears that until William Richardson filed his first stit, no one did question the authority. See Richardson v. Sokol, 285 F. Supp. 866 (W.D. l’a. 1968).

125. 95 Conc. Rec. 6949 (1949) (remarks of Sen. M. Tydings); cf. Exec. Order No. $11,652, \$ 5(B)(4), 3$ C.F.R. 339,345 (1974). On the effectiveness and reliability of secret agents, see MarchetTI \& MaRks, supra note 4, at 23, 206-08. With this one exception, Congress did not set out clearly what interests it sought to protect by using those special procedures of the CIA Act. It would have been desirable for Congress to set out the interests to be protected, the alternative forms of disclosure available, the implications of each, and the tradcoffs involved. See generally United States v, Robel, 389 U.S. 258, 276 (1967) (Brennan, J., concurring); Environmental Defense Fund v. Froehlke, 473 F.2d 346 , 350-51 (8th Cir. 1972); Wellington, Common Law Rules and Constitutional Double Standards: Some Notes on Adjudication, 83 YALE L.J. 221 (1973).

126. Marchetti \& MARKs, strpra note 4, at 61 .

127. Nat'l Defense Hearings, supra note 112, at 121.

128. The secrecy of tactical operations raises more difficult questions than the need to preserve agents' lives. Some critics have argued that there is no effective control of the intelligence agencies and that they function as an "invisible government." See D. WISE $\& \mathrm{~T}$. Ross, supra note 79 . Other critics have not gone so far but have pointed to a lack of effective congressional control. See note 79 supra. In cither case it is possible to arguc that more public disclosure and discussion of the CIA's tactical operations is the only way to control the tendency toward improper covert operations-a tendency which, it is claimed, is demonstrated by the CIA's role in Watergate. See Marchetri \& MARks, supra note 4 , at $249-50$.

129. The revelation of past activities might compromise present sources, prevent similar tactics being uscd again, or damage relations with the country or countries involved.

130. On the principal example of such secrecy, the Manhattan Project to develop the atomic bomb, see note 101 supra. When overall military strategy is based on deterrence, there are powerful arguments for revealing at least the existence of new weapons as they 
The present practices admittedly protect these interests, but they are not the only means for doing so; there are alternatives that would serve. The most obvious alternatives involve barring future undisclosed transfers from other agency budgets, appropriating the CIA's funds, either in lump sum or in detail, and including CIA expenditures, again either in lump sum or in detail, in the Combined Statement. ${ }^{131}$ The impact of the alternatives on the interests Congress sought to protect is clear. It is nearly impossible to conceive of any scenario in which open lump-sum appropriation to the CIA and an accounting for the gross sum expended by the agency would substantially enhance any danger to these interests. There are too many links in the long chain between a figure as large as the estimated $\$ 750$ million the CIA spent in $1973^{132}$ and the particulars an enemy might want to know-the whereabouts of an agent, the details of tactics, even the broad outlines of strategy. ${ }^{133}$ Although any such judgment involves elements of speculation, ${ }^{134}$ it is instructive to note

are developed. For example, the Nary has sought publicity, in order to enhance deterrent value, for a new form of torpedo mine developed secretly, but the State and Defense Departments have urged secrecy for fear that the United States will be charged with a violation of the Seabed Treaty of 1972. N.Y. Times, Apr. 15, 1974, at 16, col. 5 .

131. In 1971, Senator George S. McGovern introduced S. 2231, 92d Cong., 1st Sess. (1971). The bill provided that a single sum covering proposed appropriations and expenditures of the CIA be shown in the budget of the United States. Id. $\$ 1$. It also provided that no funds appropriated to any other department or agency could be made available for cxpenditure by the CIA. Id. $\$ 2$. The single figure would "allow the Congress to exercise its constitutional powers over Federal finances," but would not "endanger national security" by communicating "usable information to potential adversaries." 117 CoNG. REC. 23692 (1971) (remarks of Sen. McGovern). The bill died in the Armed Services Committec.

132. 119 Conc. Rec. S6868 (daily ed. Apr. 10, 1973) (remarks of Sen. Proxmire); MarCHETTI \& MARKs, supra note 4 , at 59 .

133. Even strong supporters of the CIA have maintained that neither the CIA nor national security would be harmed by disclosure of its aggregate budget. Interview with Lyman Kirkpatrick, supra note 77; Interview with Elliot Richardson, former Sec'y of Defense, in New Haven, Conn., Apr. 2, 1974. As Allen Dulles noted, the withholding of too much information may hurt the CIA, since certain information must be given out if public confidence in the intelligence mission is to be strengthened. See A. DuL.LEs, supra note 79 , at 8 . This view is, of course, not unanimously held; for example, Clay Whitehead, former Director of Telecommunications Policy of the Executive Office of the President, feels that revealing even the aggregate budget of the CIA would enable other nations to determine our intelligence capabilities. Interview with Clay whitehead in New Haven, Conn., Mar. 26, 1974.

134. It is possible to argue that people outside of the CIA, not having access to secret information, cannot evaluate the impact of change on the agency or national security. Such an argument cannot be answered fully. It asks that ideas not be tested in the marketplace but that they be accepted on the basis of unchallengeable authority. So it is with secrecy. It is obviously difficult to define what should be kept secret in order not to impair the national security without knowing what is presently kept secret and why; the act of definition of the interests to be protected may in itself threaten national security. Among the facts which are currently being withheld on the basis of national sccurity are: the executive order establishing the National Security Agency (NSA) in 1952, D. KAHN, The CODE BREAKERs 675 (1967); the existence of the National Reconnaissance Office which spends over a billion dollars a year, Wash. Post, Dec. 9, 1973, at A9, col. 8; the number of Secret Service agents who were guarding the recently resigned Vice P'resident, N.Y. Times, Feb. 14, 1974, at 21, col. 1; the reasons for the surveillance of former President Nixon's brother, N.Y. Times, Feb. 18, 1974, at 25, col. 1. 
that aggregate budget figures for a related agency, the Defense Intelligence Agency, have been made known without any hint that such publication has caused significant national security problems. ${ }^{135}$

The present funding and disclosure practices thus cannot be justified by invoking national security. They are unconstitutional and should be replaced. The Constitution requires, at a minimum, lumpsum appropriation and accounting, and an end to secret transfer of funds. Implementing these measures would prevent the funding and disclosure practices from clashing so blatantly with the requirements of the Clause. But if nothing beyond lump-sum appropriations by Congress and revelations of aggregate expenditures is accomplished, it may well be asked just how much has been gained. The achievement is small, but an achievement nonetheless. Possessing such information, the public-and Congress-could more accurately assess the nation's spending priorities, measuring the CIA's claim on the public treasury against other national endeavors. The public and the Congress would also have a notion of the level of CIA activity from year to year. Congress would have to live up to its constitutional responsibility of determining policy and priorities; forcing Congress as a whole to appropriate funds to the agency would mean that it could no longer pass that responsibility to the Executive-along with any potential blame for CIA activities that later prove unpopular. Congress would therefore have far greater incentive to inform itself about the activities for which it is providing the funds.

Congress could, of course, always require appropriation and disclosure ${ }^{130}$ beyond lump-sum amounts, but it is hard to be optimistic that the courts would read the Clause as mandating more specific appropriations or more detailed disclosure. Yet such a reading is not implausible. If one examines the purposes of the Clause and asks that appropriations and disclosure practices seek to accomplish them to the fullest extent possible without posing an unreasonable threat to national security, then the Clause requires greater detail, ${ }^{137}$ as to

135. See The Forces that Monilor and Prolect, Tims, Junc 4, 1973, at 24.

136. Congressional interest in providing access to information which had been cxcmpted from disclosure under the national sccurity cxception to the Freedom of Information Act, 5 U.S.C. $\$ 552(b)(3)(1970)$, can be secn in a report by the House Government Operations Committe on the recent amendments to the Freedom of Information $A$ ct. Sce H.R. Rep. No. 876, 93d Cong., 2d Sess. 7-8, 11-14 (1974). President's Ford's veto of the amendment was overridden by Congress. See N.Y. Times, Nov. 22, 1974, at 21, col. 3. For the 1974 amendments themselves, see 1974 Amendments to the Freedom of Information .Ict, Pub. L. No. 93-502 (Nov. 21, 1974).

137. Even lump-sum appropriation and disclosure would prevent both Congress and the public from fixing or analyzing internal priorities within the CIA; it would also be impossible to determine if there has been waste, corruption, or spending prohibited by statute or by the Constitution. 
both appropriations and accounting. The difficulty lies in determining how much detail; the constitutional text provides little guidance. But perhaps the present practices of most governmental agencies provide a standard. It might be argued on such a basis that appropriation by and publication of a program classification budget and an object classification budget are required for every agency, or possibly for every unit within an agency which spends more than a certain amount. ${ }^{138}$ Whether such detail could reasonably be expected to result in placing an agent in danger or in compromising a tactical operation ${ }^{139}$ seems a closer question than that raised by lump-sum disclosure. It does seem unlikely that the publication of figures which indicate that $X$ million dollars are spent on rent, $Y$ million on personnel, and $Z$ million on data collection would have the feared results. ${ }^{140}$ Where there is a reasonable probability that disclosure could substantially threaten national security interests, the recourse would be to appropriate and report these specific funds as expended for confidential purposes, as is now done by the AEC and other agencies. $^{141}$ Details of other appropriations and expenditures would still be published.

138. It might be possible constitutionally to require specific appropriations and disclosure by any governmental unit which spends in excess of a certain sum (expressed either as a fixed dollax amount or as a percentage of the total budget) whether or not that unit is part of a larger agency. Even a figure as small as one hundredth of one percent of the aggregate budget would now be roughly $\$ 30$ million. Under such a system, units with a significant expenditure of funds would receive specific appropriations and be required to make reports. Such a requirement would increase congressional control over policy and priorities and would provide cnormous amounts of information to the public. It would also climinate the possibility that the CIA could simply be merged into a larger department to provide continuing concealment of expenditures from Congress and the public-a genuine possibility if the courts hold that the Clause requires only that cach separate agency receive a lump-sum appropriation and make a lump-sum accounting.

While it might be difficult for courts to develop and apply a fixed numerical standard of this sort, such an action would not be unprecedented. See Whitc v. Regester, 412 U.S. 755 (1973) (upholding Texas reapportionment plan which contained maximum population deviation between districts of 9.9 percent); Gaffney v. Cummings, 412 U.S. 735 (1973) (upholding Connecticut reapportionment plan which contained maximum population deviation between districts of 7.83 percent). Of these two decisions the dissenters wrote:

Since the Court expresses no misgivings about our recent decision in Abate v. Mundt,

403 U.S. $182 \ldots(1971)$, where we held that a total deviation of $11.9 \%$ must be justified

by the State, one can reasonably surmise that a line has been drawn at $10 \%$-deviations in excess of that amount are apparently acceptable only on a showing of justi-

fication by the State; deviations of less than that amount require no justification whatsoever.

$I d$. at 777 (Brennan, J., dissenting).

139. See note 106 supra.

140. Elliot Richardson, however, has indicated that publication of the aggregate budget would probably not cause any substantial difficulty, but that further breakdowns would allow other nations to detect the emphasis which we are placing on various areas, and that that would harm the national security. Interview with Elliot Richardson, supra note 133.

141. For example, if it were determined that disclosure of the total figure spent on covert personnel by the CIA could reasonably be expected to cause substantial damage to the national security, it could be omitted from the object classification "personnel" and lumped with "confịdential purposes." 
Constitutional requirements of appropriation and disclosure should apply not only to the CIA, but also to the National Security Agency, the Defense Intelligence Agency, and to the intelligence branches of the armed forces. ${ }^{142}$ It is estimated that these agencies, along with the CIA, spend between four and ten billion dollars annually; ${ }^{143}$ they currently vary considerably in the extent of their disclosure of receipts and expenditures. ${ }^{144}$ In each case the appropriation procedures and the level of disclosure of receipts and expenditures would be scrutinized to determine their relationship to the accomplishment of the goals which Congress set for the agency, and the effect on the interests sought to be protected by the legislation of alternatives involving greater disclosure. If disclosure could not reasonably be expected to do substantial damage to these interests, ${ }^{145}$ fuller disclosure would be mandated. The minimum, as with the CIA, would be lump-sum appropriation and accounting.

\section{Conclusion}

The beginnings of the Cold War drastically altered the appropriations process and the availability of information about appropriations and expenditures, particularly in regard to agencies which operate in the area of foreign intelligence. The changes made it difficult, if not impossible, to accomplish the purposes for which Article I, $\S 9$, Clause 7, was adopted. Congress ceased to exercise effective control over the purse by virtually delegating its appropriations power to another body; both Congress and the people were prevented from

142. See 119 ConG. REC. $S 6868$ (daily ed. Apr. 10, 1973); The Forces that Monitor and Protect, TIME, June 4, 1973, at 24; MARchetri \& MARKS, supra note 4, at 80.

143. Lyman Kirkpatrick, former Executive Director-Comptroller of the CIA, estimated intelligence expenditures at between four and six billion dollars annually. Interview with Lyman Kirkpatrick, supra note 77 . Senator Proxmire estimated expenditures for foreign intelligence at approximately six billion dollars annually. 119 CoNG. REc. S6868 (daily ed. Apr. 10, 1973). Andrew St. George estimated expenditures for intelligence at close to ten billion dollars annually. The Cold War Comes Home, HARIER's MAG., Nov. 1973, at 78.

Perhaps onc of the reasons for the disparity in estimates is the difficulty in agreeing as to which costs should be assigned to intelligence functions and which costs should be assigned to other budget categories. This is particularly true in regard to the intelligence activities of the various armed services. See 117 CoNs. Rec. 42923-34 (1971).

144. Ior example, the NSA, unlike the CIA, docs not cven provide information about construction. Its appropriations and expenditures are reported with those of the Defense Department, but the total of its expenditures are witheld. Letter from Roy $R$. Banner, General Counsel of the NSA, to Elliot E. Maxwell, Feb. 13, 1974 (on file with the Yale Law Journal). The NSA is even larger and more expensive than the CIA; estimates of its annual budget range from one to two billion dollars. Even the executive order establishing the NS. 1 in 1952 has been withheld from the public. See D. KAHN, THE Code-breakers, 383-84 (Signet ed. 1973); 119 CoNc. Rec. S6868 (daily ed. Apr. 10, 1973) (remarks of Sen. Proxmire); Marchetti \& Marks, supra note 4, at 59-73.

145. See note 106 supra. 
checking expenditures for constitutionality, legality, public acceptance, and waste. Congress must as a whole regain control over the appropriations power and must reassert its supervisory role over the CIA; the people must not be deprived of their right to know how the public money is being spent. There are certain instances in which the withholding of details about appropriations and expenditures is justified. But the importance of the information for the operation of a democratic society requires that such exceptions to the constitutionally mandated policy of disclosure be minimized, ${ }^{146}$ and the public ensured access to the maximum possible budgetary information.

146. See Soucie v. David, 448 F.2d 1067, 1078 (D.C. Cir. 1971). 